\title{
Urgences
}

\section{Au bord du rêve...}

\section{Jean Antonin Billard}

Numéro 29, octobre 1990

\section{Éclats d'œuvre}

URI : https://id.erudit.org/iderudit/025611ar

DOI : https://doi.org/10.7202/025611ar

Aller au sommaire du numéro

Éditeur(s)

Urgences

\section{ISSN}

0226-9554 (imprimé)

1927-3924 (numérique)

Découvrir la revue

Citer ce document

Billard, J. A. (1990). Au bord du rêve... Urgences, (29), 75-75.

https://doi.org/10.7202/025611ar d'utilisation que vous pouvez consulter en ligne.

https://apropos.erudit.org/fr/usagers/politique-dutilisation/ 


\section{Jean Antonin Billard}

Au bord du rêve de l'autre, mon écriture vacille, prise au vertige des profondeurs de l'être que je survole, incertain du temps que j'ai. Fragmenté, il n'a plus de fin. J'entre ainsi dans la fiction de l'éternel recommencement du papillon accroché à sa falaise qui fait bouger les pierres. 